Génét. Sél. Evol., 1983, 15 (3), 455-460

NOTE

\title{
The prevalence of heterozygotes for $\alpha$-mannosidosis in populations of Angus, Galloway and Murray Grey cattle in New South Wales
}

\author{
P.J. HEALY \\ New South Wales Department of Agriculture, \\ Veterinary Research Station, Roy Watts Road \\ Glenfield, New South Wales, 2167, Australia
}

\begin{abstract}
Summary
Samples from 24503 cattle of 3 breeds were examined to detect heterozygotes for the lysosomal storage disease $\alpha$-mannosidosis. Diagnoses were based upon results of plasma or serum and granulocyte tests. The prevalence of heterozygotes for $\alpha$-mannosidosis was $5.6 \%$ for registered Angus, $5.4 \%$ for Red Angus, $15.9 \%$ for commercial Angus, $17.9 \%$ for Galloways and $2.8 \%$ for Murray Greys.
\end{abstract}

Key-words : Bovine - $\alpha$-mannosidosis - heterozygote - detection.

Résumé

Fréquence des hétérozygotes pour l'alpha-mannosidose dans les races bovines Angus, Galloway et Murray Grey des Nouvelles-Galles du Sud

Un échantillon de 24503 bovins des races Angus, Galloway et Murray-Grey a été examiné en vue de la détection d'individus hétérozygotes pour l'alpha-mannosidose, maladie métabolique liée à une déficience des lysosomes. Le diagnostic individuel repose sur des tests quantifiant l'activité de l'alpha-mannosidase dans les plasma ou sérum et granulocytes. La fréquence des hétérozygotes ainsi détectés est de : $5,6 \%$ dans le bétail Angus inscrit, 5,4\% en Red Angus, 5,9\% en Angus commercial; $17,9 \%$ en Galloway et $2,8 \%$ en Murray-Grey.

Mots-clés : Bovins - $\alpha$-mannosidose - hétérozygote - détection.

\section{Introduction}

$\alpha$-Mannosidosis is an inborn error of metabolism characterised by an accumulation of glycoprotein residues within lysosomes as a consequence of a deficiency of lysosomal $\alpha$-mannosidase activity. The disease is inherited in an autosomal recessive manner. Hetorozygotes have approximately half the activity of $\alpha$-mannosidase found in blood and tissues of homozygous normal subjects (HOCKING et al., 1972). Demonstration of this partial deficiency is the basis of tests for detection of heterozygotes (JOLLY et al., 1973). In Australia, tests for detection of heterozygotes have been adapted to suit local conditions (HeAly \& Butrej, 1979; Sinclair et al., 1979; HeAly, 1981). These tests have served as the basis for a programme implemented to reduce the prevalence of 
heterozygotes for $\alpha$-mannosidosis in herds producing Angus bulls for breeding purposes (HEALY et al., 1983). The present report gives information on the prevalence of heterozygotes in populations of Angus, Red Angus, Galloway and Murray Grey cattle in New South Wales, Australia.

\section{Materials and methods}

\section{A. Animals}

The subjects were aged between 1 week and 14 years and were of both sexes. The subjects were registered with either the Angus Society of Australia, the Red Angus Society of Australia, the Galloway Cattle Society of Australia or the Murray Grey Beef Cattle Society of Australia, with the exception of 5533 subjects in 28 commercial Angus herds. In four of these commercial Angus herds $\alpha$-mannosidosis had been confirmed by pathological and biochemical examination of affected calves.

\section{B. Samples}

Blood was collected from either the jugular vein or coccygeal vessels into $10 \mathrm{ml}$ evacuated tubes without anticoagulant; or tubes with 143 US units of heparin; or $15 \mathrm{mg}$ of the tripotassium salt of ethylene diaminotetraacetic acid (EDTA). Clotted and heparinized blood was centrifuged at $1500 \times \mathrm{g}$ for $10 \mathrm{~min}$ within 6 hours of collection and the serum or plasma harvested and then stored at $-20^{\circ} \mathrm{C}$. EDTA blood was centrifuged within 48 hours of collection and plasma either taken for analyses or frozen at $-20^{\circ} \mathrm{C}$. Granulocyte preparations were made from $20 \mathrm{ml}$ of EDTA blood within 48 hours of collection of the sample (HEALY, 1979).

\section{Analytical procedures}

Serum and plasma samples were analysed for $\alpha$-mannosidase activity using the end point colorimetric method described by HEALY \& BUTREJ (1979). Granulocyte tests were conducted using the method described by HEALY (1979).

\section{Interpretation of analytical results}

Presumptive diagnoses of the heterozygotes genotype were made if $\alpha$-mannosidase activity in serum/plasma was less than $60 \%$ of the mean of that in samples from age - and sex - matched peers (JoLly et al., 1973). Prior to the introduction of the granulocyte test in 1978, diagnoses of the heterozygote genotype were considered to be confirmed when heterozygote diagnoses were made for parent/offspring pairs. After 1978 presumptive diagnoses were confirmed using the granulocyte test.

\section{Results}

In registered cattle the prevalence of heterozygotes for $\alpha$-mannosidosis ranged from $2.8 \%$ for Murray Greys to $17.9 \%$ for Galloways. The percentage of herds containing heterozygotes varied from $49 \%$ for Murray Greys to $64 \%$ for Galloways (Table 1). In 
populations of commercial Angus cattle sampled, the prevalence of heterozygotes exceeded that in herds of registered Angus. Prevalence was high, mean $22 \%$, in commercial herds, where cases of $\alpha$-mannosidosis had been confirmed. In one such herd $31.7 \%$ of 300 Angus and Red Angus cows were found to be heterozygous.

\section{TABLE 1}

Number of cattle in New South Wales tested for detection of heterozygotes for $\alpha$-mannosidosis and numbers of heterozygotes found.

Nombre de bovins testés en Nouvelles-Galles du Sud et identifiés comme hétérozygotes pour l' $\alpha$-mannosidose.

\begin{tabular}{l|c|c|c|c}
\hline \hline \multicolumn{1}{c|}{ Group } & $\begin{array}{l}\text { No. of sub- } \\
\text { jects tested }\end{array}$ & $\begin{array}{c}\text { No. of subjects } \\
\text { diagnosed as } \\
\text { heterozygous }\end{array}$ & $\begin{array}{c}\text { No. of herds } \\
\text { sampled }\end{array}$ & $\begin{array}{c}\text { No. of herds } \\
\text { with subjects } \\
\text { diagnosed as } \\
\text { heterozygotes }\end{array}$ \\
\hline $\begin{array}{l}\text { Registered } \\
\text { Angus }\end{array}$ & 12550 & $721(5.7 \%)$ & 101 & $60(59 \%)$ \\
\hline Red Angus & 739 & $40(5.4 \%)$ & 8 & $5(63 \%)$ \\
\hline $\begin{array}{l}\text { Galloway } \\
\begin{array}{l}\text { Murray } \\
\text { Grey }\end{array}\end{array}$ & 340 & $61(17.9 \%)$ & 11 & $7(64 \%)$ \\
\hline $\begin{array}{l}\text { Commercial } \\
\text { Angus in } \\
\text { herds where } \\
\text { cases of } \\
\text { manno- } \\
\text { sidosis } \\
\text { were } \\
\text { reported }\end{array}$ & 5341 & $147(2.8 \%)$ & 85 & $42(49 \%)$ \\
\hline $\begin{array}{l}\text { Commercial } \\
\text { Angus in } \\
\text { herds not } \\
\text { reporting } \\
\text { cases of } \\
\text { manno- } \\
\text { sidosis }\end{array}$ & 3086 & $669(22 \%)$ & 4 & $4(100 \%)$ \\
\hline \hline
\end{tabular}

\section{Discussion}

Heterozygotes for $\alpha$-mannosidosis were found in the Angus, Galloway and Murray Grey cattle populations. The prevalence was highest in Galloway herds and lowest in Murray Grey herds.

HART \& HEALY (1980) reported the presence of heterozygotes for $\alpha$-mannosidosis in Galloway cattle in New South Wales. Subsequently, SINCLAIR (personal communication) detected heterozygotes in Galloways in Victoria. The high prevalence of heterozygotes 
undoubtedly reflecting the limited gene pool available to breeders of Galloways in Australia. Examination of pedigrees suggests that the gene was recently introduced into Australia.

Red Angus herds in New South Wales have been developed with cattle purchased from commercial and registered herds. The cattle purchased have been those heterozygous or homozygous for the recessive gene for red coat colour, such animals bein reported in the majority of New South Wales registered Angus herds. Therefore, it is not surprising that the prevalence of $\alpha$-mannosidosis heterozygotes in Red Angus herds is similar to that in Angus cattle.

Murray Grey herds were found to have a lower prevalence of heterozygotes than the other breeds. Approximately $50 \%$ of Murray Grey herds did, however, have at least one heterozygote. In most instances, these subjects were progeny of Angus cows used as base stock in developing the Murray Grey herd.

Economic justification for schemes to control $\alpha$-mannosidosis has been considered elsewhere (JOLLY \& TOWNSLEY, 1980; JOLLY et al., 1981). Breeders of registered Angus, Red Angus and Murray Grey cattle in Australia have not considered that economic factors are the critical determinants governing the implementation of a scheme to control $\alpha$-mannosidosis in their breeds. They were willing to remove heterozygotes from their herds providing such action did not reduce the genetic pool available for selection. Fortunately, the prevalence of heterozygotes for $\alpha$-mannosidosis in Angus, Red Angus and Murray Grey cattle in Australia is relatively low, allowing removal of heterozygotes from the registered herds. The existence of an accurate test for detection of heterozygotes will, if necessary, allow retention for breeding purposes of individual heterozygotes claimed to be of particular merit, since $50 \%$ of the progeny will be homozygous normal if the individual is mated to homozygous normal animal.

\section{Conclusions}

The gene for $\alpha$-mannosidosis occurs in Angus, Red Angus, Galloway and Murray Grey cattle in New South Wales. Heterozygote detection based upon serum/plasma and granulocyte tests will allow a rapid reduction in the prevalence of heterozygotes in bull-producing herds and, in the long term, a very low prevalence of the disease. In Angus, Red Angus and Murray Grey herds, culling of heterozygotes from bull-producing herds is recommended. Due to a high prevalence of heterozygotes in some Galloway herds, and a limited gene pool, retention of heterozygotes may be necessary to avoid loss from the genetic pool.

\section{Acknowledgments}

I wish to thank Mrs P. ButreJ and Mrs C. Sewell for their untiring efforts in the analyses of samples and collection of pedigree data. 


\section{References}

Hart K.G., Healy P.J., 1980. Galloway cattle heterozygous for mannosidosis. Austr., Vet. J., 56, 255-256.

HeAly P.J., 1979. Tests for detection of cattle heterozygous for $\alpha$-mannosidosis. Australian Bureau of Animal Health.

HEAlY P.J., COLE A.E., 1976. Heterozygotes for mannosidosis in Angus and Murray Grey cattle. Austr., Vet. J., 52, 385-386.

Healy P.J., Butrej P.J., 1979. Use of EDTA blood samples for mannidosis testing. Austr. Vet. J., 55, 534-536.

Healy P.J., Harrison M.A., Sinclair A.J., Judson G., Mason R.M., Peterson D., 1983. Prevalence of heterozygotes for $\alpha$-mannosidosis in registered Angus cattle in Australia. Austr. Vet. $J$. (in press).

Hocking J.D., Jolly R.D., BatT R.D., 1972. Deficiency of $\alpha$-mannosidase in Angus Cattle. Biochem. J., 128, 69-78.

Jolly R.D., TSE C.A., GReEnway R.M., 1973. Plasma $\alpha$-mannosidase activity as a means of detecting mannosidosis heterozygotes. N.Z. Vet. J., 21, 64-69.

JOLLY R.D., TOWNSLEY R.J., 1980. Genetic screening programmes: an analysis of benefits and costs using the bovine mannosidosis scheme as a model. N.Z. Vet. J., 28, 3-6.

Jolly R.D., DoddS W.J., Ruth G.R., Trauner D.R., 1981. Screening for Genetic Diseases. Princ. Pract. Adv. Vet. Sci. Comp. Med., 25, 245-276.

SinclatR A.J., Embury D.H., ALLEN J.D., 1979. An improved fluorimetric determination of $\alpha$-mannosidase activity in bovine plasma. Austr. Vet. J., 55, 236-239. 